Vol. 1 No. 2 Desember 2021, e-ISSN : 2807-8667| p-ISSN : 2807-8837

\title{
IMPLEMENTASI STRATEGI GUIDED TEACHING TERHADAP PEMAHAMAN MATERI TALKING ABOUT SELF PADA SISWA KELAS X AKUNTANSI DAN KEUANGAN LEMBAGA
}

\author{
GIARTI \\ SMK Negeri 1 Tanah Grogot \\ e-mail: giartimujahidin@gmail.com
}

\begin{abstract}
ABSTRAK
Setiap akan mengajar, guru perlu membuat persiapan mengajar dalam rangka melaksanakan sebagian dari rencana bulanan dan rencana tahunan. Dalam perisiapan itu sudah terkandung tentang, tujuan mengajar, pokok yang akan diajarkan, metode mengajar, bahan pelajaran, alat peraga dan teknik evaluasi yang digunakan. Karena itu setiap guru harus memahami benar tentang tujuan mengajar, secara khusus memilih dan menentukan metode mengajar sesuai dengan tujuan yang hendak dicapai, cara memilih, menentukan dan menggunakan alat peraga, cara membuat tes dan menggunakannya, dan pengetahuan tentang alat-alat evaluasi. Tujuan penelitian yang hendak diperoleh adalah: (a) Untuk mengungkap pengaruh Metode Strategi Guided Teaching terhadap kemampuan berbicara menggunakan Bahasa Inggris. (b) Untuk mengungkap Metode Strategi Guided Teaching terhadap motivasi belajar Bahasa Inggris. Penelitian ini menggunakan penelitian tindakan (action research) sebanyak tiga putaran. Setiap putaran terdiri dari empat tahap yaitu: rancangan, kegiatan dan pengamatan, refleksi, dan refisi. Sasaran penelitian ini adalah siswa Kelas X Data yang diperoleh berupa hasil tes formatif, lembar observasi kegiatan belajar mengajar. Dari hasil analisis didapatkan bahwa prestasi belajar siswa mengalami peningkatan dari siklus I sampai siklus III yaitu, siklus I (66\%), siklus II (74\%), siklus III (89\%). Simpulan dari penelitian ini adalah gabungan metode ceramah dengan kelompok kerja dapat berpengaruh positif terhadap prestasi dan motivasi belajar Siswa kelas x Akuntansi dan Keuangan Lembaga 1 Tahun Pelajaran 2018/2019, serta model pembelajaran ini dapat digunakan sebagai salah satu alternative pembelajaran Bahasa Inggris . Kata Kunci : Strategi Guided Teaching, Materi Talking About Self, Pemahaman Siswa
\end{abstract}

\section{ABSTRACT}

Every time they teach, teachers need to make teaching preparations in order to carry out part of the monthly plan and annual plan. The preparation contains the objectives of teaching, the subject to be taught, teaching methods, learning materials, teaching aids and evaluation techniques used. Therefore, every teacher must understand correctly about the purpose of teaching, specifically choosing and determining teaching methods according to the objectives to be achieved, how to choose, determine and use teaching aids, how to make tests and use them, and knowledge of evaluation tools. The research objectives to be obtained are: (a) To reveal the effect of the Guided Teaching Strategy Method on the ability to speak using English. (b) To reveal the Guided Teaching Strategy Method on the motivation to learn English. This research uses three rounds of action research. Each round consists of four stages, namely: design, activities and observations, reflection, and revision. The targets of this study were students of Class X. The data obtained were in the form of formative test results, observation sheets for teaching and learning activities. From the results of the analysis, it was found that student achievement increased from cycle I to cycle III, namely, cycle I (66\%), cycle II (74\%), cycle III (89\%). The conclusion of this study is that the combination of the lecture method with the work group can have a positive effect on the achievement and learning motivation of Class X Accounting and Financial Institutions 1st Academic Year 2018/2019, and this learning model can be used as an alternative to learning English.

Keywords: Guided Teaching Strategy, Talking About Self Material, Student Understanding 


\section{PENDAHULUAN}

Manusia tumbuh dan berkembang sejak dalam kandungan. Dalam pertumbuham dam perkembangannya, manusia membutuhkan tuntunan melalui proses pendidikan, pendidikan sebagai suatu proses membimbing kemampuan atau bakat manusia, mempengaruhi dan menyempurnakannya dengan pembiasaan yang baik melalui saran yang telah dipersiapkan dalam mencapai tujuan yang diharapkan.

Pendidikan adalah usaha sadar yang dilakukan oleh keluarga, masyarakat dan pemerintah melalui bimbingan, pengajaran dan pelatihan yang berlangsung di sekolah dan diluar sekolah sepanjang hayat. Untuk mempersiapkan peserta didik agar dapat memainkan peranan dalam berbagai lingkungan hidup secara tepat dimasa mendatang. Pendidikan adalah pengalaman-pengalaman belajar terprogram dalam bentuk pendidikan formal dan non formal, dan informal di sekolah, dan diluar sekolah, yang berlangsung seumur hidup yang bertujuan optimalisasi pertimbangan kemampuan-kemampuan individu agar kemudian hari dapat memainkan peranan secara tepat.

Sebagaimana yang disebutkan dalam Undang-undang Sistem Pendidikan Nasional Nomor 20 tahun 2003 Bab I Pasal I ayat 10 yang berbunyi: "Satuan pendidikan adalah kelompok layanan pendidikan yang menyelenggarakan pendidikan pada jalur formal, nonformal, dan informal pada setiap jenjang dan jenis pendidikan".

Memasuki era persaingan global seperti sekarang ini masalah pendidikan, termasuk juga pendidikan agama memegang peranan penting dan tanggung jawab yang paling besar dalam menyiapkan sumber daya manusia yang berkualitas. Apalagi pendidikan agama merupakan landasan moral dalam melaksanakan pembangunan tersebut. Hal ini sesuai dengan hal yang dikemukakan oleh para ahli pendidikan bahwasanya pendidikan merupakan kunci yang membuka pintu pembangunan. Atas dasar itulah sekolah sebagai salah satu lembaga pendidikan harus berperan sebagai wahana untuk memberikan latihan bagaimana cara belajar. Melalui kemampuan bagaimana cara belajar, siswa akan dapat belajar memecahkan setiap rintangan yang dihadapi sampai akhir hayat. Guru sebagai komponen penting dari tenaga kependidikan, memiliki tugas untuk melaksanakan proses pembelajaran. Dalam proses pembelajaran akan berjalan secara optimal perlu adanya rencana pembuatan strategi pembelajaran.

Pengertian strategi pembelajaran dapat dikaji dari dua kata pembentuknya, yaitu strategi dan pembelajaran. Strategi menurut Arthur L. Costa (1985) seperti yang dikutip oleh Rustaman $(2003$; 3) merupakan pola kegiatan pembelajaran berurutan yang diterapkan dari waktu ke waktu dan diarahkan untuk mencapai suatu hasil belajar siswa yang diinginkan.

Salah satu cara untuk menata dan mengorganisasi isi pembelajaran adalah dengan menggunakan strategi Guided Teaching. Penggunaan strategi Guided Teaching memiliki caracara yang sistematis dalam mengurutkan isi pembelajaran dari mudah ke sulit, dari sederhana ke kompleks. Belajar yang berhasil meski melalui berbagai macam aktivitas, baik aktivitas fisik maupun psikis. Aktivitas fisik ialah peserta didik giat, aktif dengan anggota badan, membuat sesuatu, bermain atau bekerja, ia tidak hanya duduk dan mendengarkan, melihat atau hanya pasif. Peserta didik yang memiliki aktivitas psikis (kejiwaan) adalah jika daya jiwanya bekerja sebanyak- banyaknya atau banyak berfungsi dalam rangka pengajaran. Seluruh peranan dan kemauan dikerahkan dan diarahkan supaya daya itu tetap aktif untuk mendapatkan hasil pengajaran yang optimal sekaligus mengikuti pelajaran secara aktif.

Salah satu strategi yang bersifat aplikatif dan menyenangkan adalah strategi Guided Teaching. Strategi Guided Teaching adalah cara belajar aktif dan partisipatif untuk mengembangkan pengalaman siswa. Strategi Guided Teaching adalah cara belajar aktif dan partisipatif untuk mengembangkan pengalaman siswa (Agus Suprijono, 2009: 115).

Karena disini setiap individu diberi kebebasan untuk mengeluarkan segala aspirasi yang dimilikinya demi mencari jawaban yang dapat membuat dirinya puas. Sehingga dapat menerapkan materi yang ia terima dan siswa dapat memperagakan sesuai dengan pengetahuan dalam perkembangan ranah kognitifnya yang telah ia peroleh dengan baik dan benar. 


\section{METODE PENELITIAN}

Penelitian ini merupakan penelitian tindakan (action research), karena penelitian dilakukan untuk memecahkan masalah pembelajaran di kelas. Penelitian ini juga termasuk penelitian deskriptif, sebab menggambarkan bagaimana suatu teknik pembelajaran diterapkan dan bagaimana hasil yang diinginkan dapat dicapai. Dalam penelitian ini menggunakan bentuk guru sebagai peneliti, dimana guru sangat berperan sekali dalam proses penelitian tindakan kelas. Dalam bentuk ini, tujuan utama penelitian tindakan kelas ialah untuk meningkatkan praktik- praktik pembelajaran di kelas. Dalam kegiatan ini, guru terlibat langsung secara penuh dalam proses perencanaan, tindakan, observasi, dan refleksi. Kehadiran pihak lain dalam penelitian ini peranannya tidak dominan dan sangat kecil.

Penelitian ini mengacu pada perbaikan pembelajaran yang berkesinambungan. Kemmis dan Taggart (1988:14) menyatakan bahwa model penelitian tindakan adalah berbentuk spiral. Tahapan penelitian tindakan pada suatu siklus meliputi perencanaan atau pelaksanaan observasi dan refleksi. Siklus ini berlanjut dan akan dihentikan jika sesuai dengan kebutuhan dan dirasa sudah cukup. Subyek penelitian adalah siswa-siswi Kelas X AKL 1 SMK Negeri 1 Tanah Grogot tahun pelajaran Bahasa Inggris Materi Talking about Self Pelajaran $2018 / 2019$.

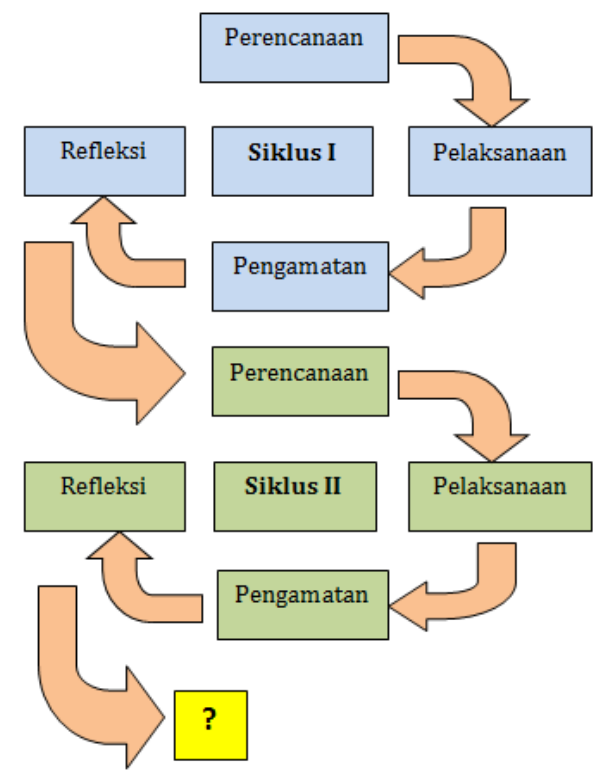

Gambar 1. Skema Penelitian Tindakan Kelas

\section{HASIL DAN PEMBAHASAN}

\section{Hasil}

Suatu pokok bahasan atau sub pokok bahasan dianggap tuntas secara klasikal jika siswa yang mendapat nilai 65 lebih dari atau sama dengan $85 \%$, sedangkan seorang siswa dinyatakan tuntas belajar pada pokok bahasan atau sub pokok bahasan tertentu jika mendapat nilai minimal 70 .

\section{Siklus I}

\section{Tahap Perencanaan}

Pada tahap ini peneliti mempersiapkan perangkat pembelajaran yang terdiri dari rencana pelajaran 1, soal tes formatif 1 dan alat-alat pengajaran yang mendukung. Selain itu juga dipersiapkan lembar observasi pengelolaan Guide Teaching, dan lembar observasi aktivitas guru dan siswa. 


\section{Tahap Kegiatan dan Pelaksanaan}

Pelaksanaan kegiatan belajar mengajar untuk siklus I dilaksanakan pada tanggal 26 Juli Tahun 2018 di Kelas X AKL 1 jumlah siswa 26 siswa. Dalam hal ini peneliti bertindak sebagai pengajar. Adapun proses belajar mengajar mengacu pada rencana pelajaran yang telah dipersiapkan. Pengamatan (observasi) dilaksanakan bersamaan dengan pelaksanaan belajar mengajar.

Pada akhir proses belajar mengajar siswa diberi tes formatif I dengan tujuan untuk mengetahui tingkat keberhasilan siswa dalam proses belajar mengajar yang telah dilakukan. Adapun data hasil penelitian pada siklus I adalah sebagai berikut.

Tabel 1. Nilai Tes Formatif Pada Siklus I

\begin{tabular}{|c|c|c|c|c|}
\hline \multirow[b]{2}{*}{ No } & \multirow[b]{2}{*}{ Nama Siswa } & \multirow[b]{2}{*}{ Skor } & \multicolumn{2}{|c|}{ Keterangan } \\
\hline & & & $\mathrm{T}$ & TT \\
\hline 1. & ZAINUDDIN RIFQI & 100 & $\sqrt{ }$ & \\
\hline 2. & AHMAD HUSAINI & 60 & & $\sqrt{ }$ \\
\hline 3. & $\begin{array}{l}\text { ANDI GHAIDA } \\
\text { TSURAYA }\end{array}$ & 80 & $\sqrt{ }$ & \\
\hline 4. & $\begin{array}{l}\text { ARINDA EKA } \\
\text { RAHMAWATI }\end{array}$ & 60 & & $\sqrt{ }$ \\
\hline 5. & AYU WULANDARI & 70 & $\sqrt{ }$ & \\
\hline 6. & $\begin{array}{l}\text { CINDI NOVITA } \\
\text { RAHMA SAS }\end{array}$ & 80 & $\sqrt{ }$ & \\
\hline 7. & $\begin{array}{l}\text { ELIS SANTI } \\
\text { SIMAMORA }\end{array}$ & 70 & $\sqrt{ }$ & \\
\hline 8. & ERI KRISTINA & 50 & & $\sqrt{ }$ \\
\hline 9. & GETA AFRIYANI & 70 & $\sqrt{ }$ & \\
\hline 10. & IIF IFTIYANI & 40 & & $\sqrt{ }$ \\
\hline 11. & IKBAL HENDRIYAN & 90 & $\sqrt{ }$ & \\
\hline 12. & INDAH MAHARANI & 80 & $\sqrt{ }$ & \\
\hline 13. & JUMAINAH & 50 & 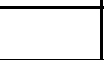 & $\checkmark$ \\
\hline 14. & KRISTIA MAULIANA & 70 & $\sqrt{ }$ & \\
\hline 15. & $\begin{array}{l}\text { LALU TEGAR } \\
\text { ARDANI }\end{array}$ & 70 & $\sqrt{ }$ & \\
\hline 16. & MARHANI & 80 & $\sqrt{ }$ & \\
\hline 17. & $\begin{array}{l}\text { MARSHA RANAZKA } \\
\text { PUTRI }\end{array}$ & 70 & $\sqrt{ }$ & \\
\hline 18. & LISTIA HANDAYANI & 50 & & $\sqrt{ }$ \\
\hline 19. & $\begin{array}{l}\text { MUHAMMAD ALFAN } \\
\text { KHOIRI }\end{array}$ & 60 & & $\sqrt{ }$ \\
\hline 20. & NOR RIA AMALIA & 100 & $\sqrt{ }$ & \\
\hline 21. & NORHIDAYAT & 70 & $\sqrt{ }$ & \\
\hline
\end{tabular}

Keterangan:

$\mathrm{T}:$ Tuntas

TT : Tidak tuntas

Jumlah Siswa yang tuntas : 28

Jumlah Siswa yang tidak tuntas : 14

Skor Maksimal Ideal : 4200

Skor Tercapai : 2955

Rata-rata Skor Tercapai : 70.3

Prosentase Ketuntasan : 66 
Tabel 2. Rekapitulasi Hasil Tes Formatif Siswa Pada Siklus I

\begin{tabular}{|c|c|c|}
\hline No & Uraian & Hasil Siklus I \\
\hline 1 & Nilai rata-rata tes formatif & 70,3 \\
\hline 2 & $\begin{array}{c}\text { Jumlah siswa yang tuntas } \\
\text { belajar }\end{array}$ & 28 \\
\hline 3 & Persentase ketuntasan & 66 \\
\hline
\end{tabular}

Dari tabel di atas dapat dijelaskan bahwa dengan menerapkan pembelajaran dengan Guide Teaching diperoleh nilai rata-rata prestasi belajar siswa adalah 70,3dan ketuntasan belajar mencapai $66 \%$ atau ada 28 siswa dari 42 siswa sudah tuntas belajar. Hasil tersebut menunjukkan bahwa pada siklus pertama secara klasikal siswa belum tuntas belajar, karena siswa yang memperoleh nilai 65 hanya sebesar $66 \%$ lebih kecil dari persentase ketuntasan yang dikehendaki yaitu sebesar $85 \%$. Hal ini disebabkan karena siswa masih merasa baru dan belum mengerti apa yang dimaksudkan dan digunakan guru dengan menerapkan pembelajaran dengan Guide Teaching.

\section{Refleksi}

Dalam pelaksanaan kegiatan belajar mengajar diperoleh informasi dari hasil pengamatan sebagai berikut:

1) Guru kurang maksimal dalam memotivasi siswa dan dalam menyampaikan tujuan pembelajaran

2) Guru kurang maksimal dalam pengelolaan waktu

3) Siswa kurang aktif selama pembelajaran berlangsung

\section{Refisi}

Pelaksanaan kegiatan belajar mengajar pada siklus I ini masih terdapat kekurangan, sehingga perlu adanya revisi untuk dilakukan pada siklus berikutnya.

1) Guru perlu lebih terampil dalam memotivasi siswa dan lebih jelas dalam menyampaikan tujuan pembelajaran. Dimana siswa diajak untuk terlibat langsung dalam setiap kegiatan yang akan dilakukan.

2) Guru perlu mendistribusikan waktu secara baik dengan menambahkan informasiinformasi yang dirasa perlu dan memberi catatan.

3) Guru harus lebih terampil dan bersemangat dalam memotivasi siswa sehingga siswa bisa lebih antusias.

\section{Siklus II}

\section{Tahap perencanaan}

Pada tahap ini peneliti mempersiapkan perangkat pembelajaran yang terdiri dari rencana pelajaran 2 , soal tes formatif 2 dan alat-alat pengajaran yang mendukung.

\section{Tahap kegiatan dan pelaksanaan}

Pelaksanaan kegiatan belajar mengajar untuk siklus II dilaksanakan pada tanggal 02 Agustus 2018 di Kelas X dengan jumlah siswa 42 siswa. Dalam hal ini peneliti bertindak sebagai pengajar. Adapun proses belajar mengajar mengacu pada rencana pelajaran dengan memperhatikan revisi pada siklus I, sehingga kesalahan atau kekurangan pada siklus I tidak terulang lagi pada siklus II. Pengamatan (observasi) dilaksanakan bersamaan dengan pelaksanaan belajar mengajar. Pada akhir proses belajar mengajar siswa diberi tes formatif II dengan tujuan untuk mengetahui tingkat keberhasilan siswa dalam proses belajar mengajar yang telah dilakukan. Instrumen yang digunakan adalah tes formatif II. Adapun data hasil penelitian pada siklus II adalah sebagai berikut. 
Dengan penyempurnaan aspek-aspek I atas alam penerapan metode pembelajarn Guide Teaching diharapkan siswa dapat menyimpulkan apa yang telah mereka pelajari dan mengemukakan pendapatnya sehingga mereka akan lebih memahami tentang apa yang telah mereka lakukan

Tabel 3. Nilai Tes Formatif Pada Siklus II

\begin{tabular}{|c|c|c|c|c|}
\hline \multirow[b]{2}{*}{ No } & \multirow[b]{2}{*}{ Nama Siswa } & \multirow[b]{2}{*}{ Skor } & \multicolumn{2}{|c|}{ Keterangan } \\
\hline & & & $\mathrm{T}$ & TT \\
\hline 1. & ZAINUDDIN RIFQI & 100 & $\sqrt{ }$ & \\
\hline 2. & AHMAD HUSAINI & 700 & $\sqrt{ }$ & \\
\hline 3. & $\begin{array}{l}\text { ANDI GHAIDA } \\
\text { TSURAYA }\end{array}$ & 80 & $\sqrt{ }$ & \\
\hline 4. & $\begin{array}{l}\text { ARINDA EKA } \\
\text { RAHMAWATI }\end{array}$ & 75 & $\sqrt{ }$ & \\
\hline 5. & AYU WULANDARI & 75 & $\sqrt{ }$ & \\
\hline 6. & $\begin{array}{l}\text { CINDI NOVITA } \\
\text { RAHMA SAS }\end{array}$ & 80 & $\sqrt{ }$ & \\
\hline 7. & $\begin{array}{l}\text { ELIS SANTI } \\
\text { SIMAMORA }\end{array}$ & 70 & $\sqrt{ }$ & \\
\hline 8. & ERI KRISTINA & 65 & & $\checkmark$ \\
\hline 9. & GETA AFRIYANI & 70 & $\sqrt{ }$ & \\
\hline 10. & IIF IFTIYANI & 60 & & $\checkmark$ \\
\hline 11. & IKBAL HENDRIYAN & 95 & $\sqrt{ }$ & \\
\hline 12. & INDAH MAHARANI & 85 & $\sqrt{ }$ & \\
\hline 13. & JUMAINAH & 75 & $\sqrt{ }$ & \\
\hline 14. & KRISTIA MAULIANA & 75 & $\sqrt{ }$ & \\
\hline 15. & $\begin{array}{l}\text { LALU TEGAR } \\
\text { ARDANI }\end{array}$ & 70 & $\sqrt{ }$ & \\
\hline 16. & MARHANI & 80 & $\sqrt{ }$ & \\
\hline 17. & $\begin{array}{l}\text { MARSHA RANAZKA } \\
\text { PUTRI }\end{array}$ & 70 & $\sqrt{ }$ & \\
\hline 18. & LISTIA HANDAYANI & 50 & & $\checkmark$ \\
\hline 19. & $\begin{array}{l}\text { MUHAMMAD ALFAN } \\
\text { KHOIRI }\end{array}$ & 60 & & $\checkmark$ \\
\hline 20. & NOR RIA AMALIA & 100 & $\sqrt{ }$ & \\
\hline 21. & NORHIDAYAT & 70 & $\sqrt{ }$ & \\
\hline 22. & NORLINA & 70 & $\checkmark$ & \\
\hline 23. & NUR AYU & 70 & $\sqrt{ }$ & \\
\hline 24. & $\begin{array}{l}\text { NURUL } \\
\text { KHAIRUNNISA }\end{array}$ & 75 & $\sqrt{ }$ & \\
\hline 25. & PENI & 80 & $\sqrt{ }$ & \\
\hline 26. & $\begin{array}{l}\text { PUTERI INDAH } \\
\text { LESTARI }\end{array}$ & 70 & $\checkmark$ & \\
\hline 27. & $\begin{array}{l}\text { RESYDA SYAIBATUL } \\
\text { HAMDI }\end{array}$ & 60 & & $\checkmark$ \\
\hline 28. & REZKY AMALIA & 50 & & $\checkmark$ \\
\hline 29. & RUMIAISYAH & 60 & & $\checkmark$ \\
\hline 30. & SITI FATIMAH & 85 & $\sqrt{ }$ & \\
\hline
\end{tabular}




\begin{tabular}{|r|l|r|r|r|}
\hline 31. & TESYA SABRINA & 90 & $\checkmark$ & \\
\hline 32. & VIRA PEBRI YUNITA & 85 & $\checkmark$ & \\
\hline 33. & WAHYUNI & 75 & $\checkmark$ & \\
\hline 34. & WATI SAPITRI & 90 & $\checkmark$ & \\
\hline 35. & ZALIPAH MAHARANI & 80 & $\checkmark$ & \\
\hline 36. & ZIRLY FERA ZAMIL & 60 & & $\checkmark$ \\
\hline 37. & AGUS SETIAWA & 75 & $\checkmark$ & \\
\hline 38. & LINDA ALDIANI & 50 & & $\checkmark$ \\
\hline 39. & ZAINAL & 40 & & $\checkmark$ \\
\hline 40. & ZULAIHAH HASAN & 90 & $\checkmark$ & \\
\hline 41. & MELANI & 60 & & $\checkmark$ \\
\hline 42. & ZULFA & 70 & $\checkmark$ & \\
\hline & Jumlah & 36 & 31 & 11 \\
\hline
\end{tabular}

Keterangan:

$\mathrm{T}:$ Tuntas

TT : Tidak tuntas

Jumlah Siswa yang tuntas : 31

Jumlah Siswa yang tidak tuntas : 11

Skor Maksimal Ideal : 4200

Skor Tercapai : 3690

Rata-rata Skor Tercapai : 87.8

Prosentase Ketuntasan : 73,8\%

Tabel 4.Rekapitulasi Hasil Tes Formatif Siswa Pada Siklus II

\begin{tabular}{|c|l|c|}
\hline No & \multicolumn{1}{|c|}{ Uraian } & Hasil Siklus II \\
\hline 1 & Nilai rata-rata tes formatif & 87.8 \\
\hline 2 & $\begin{array}{l}\text { Jumlah siswa yang tuntas } \\
\text { belajar }\end{array}$ & 31 \\
\hline 3 & Persentase ketuntasan belajar & 74 \\
\hline
\end{tabular}

Dari tabel di atas diperoleh nilai rata-rata prestasi belajar siswa adalah 87.8 dan ketuntasan belajar mencapai $74 \%$ atau ada 31 siswa dari 42 siswa sudah tuntas belajar. Hasil ini menunjukkan bahwa pada siklus II ini ketuntasan belajar secara klasikal telah mengalami peningkatan sedikit lebih baik dari siklus I. Adanya peningkatan kemampuan berbicara siswa ini karena setelah guru menginformasikan bahwa setiap akhir pelajaran akan selalu diadakan tes sehingga pada pertemuan berikutnya siswa lebih termotivasi untuk belajar. Selain itu siswa juga sudah mulai mengerti apa yang dimaksudkan dan diinginkan guru dengan menerapkan pembelajaran dengan Metode Pembelajaran Guide Teaching.

\section{Refleksi} berikut.

Dalam pelaksanaan kegiatan belajar diperoleh informasi dari hasil pengamatan sebagai

1) Memotivasi siswa

2) Membimbing siswa merumuskan kesimpulan/menemukan konsep

3) Pengelolaan waktu

\section{Revisi Rancangan}

Pelaksanaan kegiatan belajar pada siklus II ini masih terdapat kekurangan-kekurangan. Maka perlu adanya revisi untuk dilaksanakan pada siklus II antara lain: 
1) Guru dalam memotivasi siswa hendaknya dapat membuat siswa lebih termotivasi selama proses belajar mengajar berlangsung.

2) Guru harus lebih dekat dengan siswa sehingga tidak ada perasaan takut dalam diri siswa baik untuk mengemukakan pendapat atau bertanya.

3) Guru harus lebih sabar dalam membimbing siswa merumuskan kesimpulan/menemukan konsep.

4) Guru harus mendistribusikan waktu secara baik sehingga kegiatan pembelajaran dapat berjalan sesuai dengan yang diharapkan.

5) Guru sebaiknya menambah lebih banyak contoh soal dan memberi soal-soal latihan pada siswa untuk dikerjakan pada setiap kegiatan belajar mengajar.

\section{Siklus III}

\section{Tahap perencanaan}

Pada tahap ini peneliti mempersiapkan perangkat pembelajaran yang terdiri dari rencana pelajaran 3 , soal tes formatif 3 dan alat-alat pengajaran yang mendukung.

\section{Tahap kegiatan dan pengamatan}

Pelaksanaan kegiatan belajar mengajar untuk siklus III dilaksanakan pada tanggal 09 Agustus 2019 di Kelas X dengan jumlah siswa 42 siswa. Dalam hal ini peneliti bertindak sebagai pengajar. Adapun proses belajar mengajar mengacu pada rencana pelajaran dengan memperhatikan revisi pada siklus II, sehingga kesalahan atau kekurangan pada siklus II tidak terulang lagi pada siklus III. Pengamatan (observasi) dilaksanakan bersamaan dengan pelaksanaan belajar mengajar. Pada akhir proses belajar mengajar siswa diberi tes formatif III dengan tujuan untuk mengetahui tingkat keberhasilan siswa dalam proses belajar mengajar yang telah dilakukan. Instrumen yang digunakan adalah tes formatif III. Adapun data hasil penelitian pada siklus III adalah sebagai berikut.

Tabel 5. Nilai Tes Formatif Pada Siklus III

\begin{tabular}{|c|c|c|c|c|}
\hline \multirow[b]{2}{*}{ No } & \multirow[b]{2}{*}{ Nama Siswa } & \multirow[b]{2}{*}{ Skor } & \multicolumn{2}{|c|}{ Keterangan } \\
\hline & & & & TT \\
\hline 1. & ZAINUDDIN RIFQI & 100 & $\checkmark$ & \\
\hline 2. & AHMAD HUSAINI & 700 & $\checkmark$ & \\
\hline 3. & $\begin{array}{l}\text { ANDI GHAIDA } \\
\text { TSURAYA }\end{array}$ & 80 & $\bar{\checkmark}$ & \\
\hline 4. & $\begin{array}{l}\text { ARINDA EKA } \\
\text { RAHMAWATI }\end{array}$ & 75 & $\checkmark$ & \\
\hline 5. & AYU WULANDARI & 75 & $\checkmark$ & \\
\hline 6. & $\begin{array}{l}\text { CINDI NOVITA } \\
\text { RAHMA SAS }\end{array}$ & 80 & $\checkmark$ & \\
\hline 7. & $\begin{array}{l}\text { ELIS SANTI } \\
\text { SIMAMORA }\end{array}$ & 70 & $\sqrt{ }$ & \\
\hline 8. & ERI KRISTINA & 75 & $\checkmark$ & \\
\hline 9. & GETA AFRIYANI & 70 & $\checkmark$ & \\
\hline 10. & IIF IFTIYANI & 60 & $\checkmark$ & \\
\hline 11. & IKBAL HENDRIYAN & 95 & $\checkmark$ & \\
\hline 12. & INDAH MAHARANI & 85 & $\checkmark$ & \\
\hline 13. & JUMAINAH & 80 & $\checkmark$ & \\
\hline 14. & KRISTIA MAULIANA & 75 & $\checkmark$ & \\
\hline 15. & LALU TEGAR & 70 & $\checkmark$ & \\
\hline & ARDANI & & $\checkmark$ & \\
\hline 16. & MARHANI & 80 & $\checkmark$ & \\
\hline
\end{tabular}




\begin{tabular}{|c|c|c|c|c|}
\hline 17. & MARSHA RANAZKA & 70 & $\checkmark$ & \\
\hline & PUTRI & & $\sqrt{ }$ & \\
\hline 18. & LISTIA HANDAYANI & 70 & $\sqrt{ }$ & \\
\hline \multirow[t]{2}{*}{19.} & MUHAMMAD ALFAN & 75 & $\checkmark$ & \\
\hline & KHOIRI & & $\sqrt{ }$ & \\
\hline 20. & NOR RIA AMALIA & 10 & $\checkmark$ & \\
\hline 21. & NORHIDAYAT & 70 & $\checkmark$ & \\
\hline 22. & NORLINA & 70 & $\checkmark$ & \\
\hline 23. & NUR AYU & 70 & $\checkmark$ & \\
\hline \multirow[t]{2}{*}{24.} & NURUL & 75 & $\sqrt{ }$ & \\
\hline & KHAIRUNNISA & & $\checkmark$ & \\
\hline 25. & PENI & 80 & $\checkmark$ & \\
\hline \multirow{2}{*}{26.} & PUTERI INDAH & 75 & $\checkmark$ & \\
\hline & LESTARI & & $\checkmark$ & \\
\hline \multirow[t]{2}{*}{27.} & RESYDA SYAIBATUL & 70 & $\sqrt{ }$ & \\
\hline & HAMDI & & $\checkmark$ & \\
\hline 28. & REZKY AMALIA & 60 & $\sqrt{ }$ & $\square$ \\
\hline 29. & RUMIAISYAH & 60 & $\sqrt{ }$ & $\square$ \\
\hline 30. & SITI FATIMAH & 85 & $\sqrt{ }$ & \\
\hline \multirow[t]{2}{*}{31.} & TESYA SABRINA & 90 & $\checkmark$ & \\
\hline & YUWANDA & & $\sqrt{ }$ & \\
\hline 32. & VIRA PEBRI YUNITA & 85 & $\sqrt{ }$ & \\
\hline 33. & WAHYUNI & 75 & $\checkmark$ & \\
\hline 34. & WATI SAPITRI & 90 & $\checkmark$ & \\
\hline 35. & ZALIPAH MAHARANI & 80 & $\checkmark$ & \\
\hline 36. & ZIRLY FERA ZAMIL & 60 & & $\sqrt{ }$ \\
\hline 37. & AGUS SETIAWA & 75 & $\sqrt{ }$ & \\
\hline 38. & LINDA ALDIANI & 70 & $\sqrt{ }$ & \\
\hline 39. & ZAINAL & 55 & & $\sqrt{ }$ \\
\hline 40. & ZULAIHAH HASAN & 95 & $\checkmark$ & \\
\hline 41. & MELANI & 75 & $\checkmark$ & \\
\hline \multirow[t]{2}{*}{42.} & ZULFA & 80 & $\sqrt{ }$ & \\
\hline & Jumlah & 38 & 37 & 5 \\
\hline
\end{tabular}

Keterangan:

$\mathrm{T}:$ Tuntas

TT : Tidak tuntas

Jumlah Siswa yang tuntas : 37

Jumlah Siswa yang tidak tuntas : 5

Skor Maksimal Ideal : 3830

Skor Tercapai : 1820

Rata-rata Skor Tercapai : 91

Prosentase Ketuntasan : 89\%

Tabel 6. Hasil Formatif Siswa Pada Siklus III

\begin{tabular}{|c|l|c|}
\hline No & \multicolumn{1}{|c|}{ Uraian } & Hasil Siklus \\
\hline 1 & Nilai rata-rata tes formatif & 91 \\
\hline 2 & Jumlah siswa yang tuntas & 37 \\
\hline 3 & Persentase ketuntasan belajar & $89 \%$ \\
\hline
\end{tabular}


Berdasarkan tabel di atas diperoleh nilai rata-rata tes formatif sebesar 91 dan dari 42 siswa telah tuntas sebanyak 37 siswa dan 5 siswa belum mencapai ketuntasan belajar. Maka secara klasikal ketuntasan belajar yang telah tercapai sebesar 89\% (termasuk kategori tuntas). Hasil pada siklus III ini mengalami peningkatan lebih baik dari siklus II. Adanya peningkatan kemampuan berbicara pada siklus III ini dipengaruhi oleh adanya peningkatan kemampuan guru dalam menerapkan pembelajaran dengan metode Pembelajaran Guide Teaching sehingga siswa menjadi lebih terbiasa dengan pembelajaran seperti ini sehingga siswa lebih mudah dalam memahami materi yang telah diberikan.

\section{Refleksi}

Pada tahap ini akan dikaji apa yang telah terlaksana dengan baik maupun yang masih kurang baik dalam proses belajar mengajar dengan penerapan pembelajaran dengan Guide Teaching. Dari data- data yang telah diperoleh dapat diuraikan sebagai berikut:

1) Selama proses belajar mengajar guru telah melaksanakan semua pembelajaran dengan baik. Meskipun ada beberapa aspek yang belum sempurna, tetapi persentase pelaksanaannya untuk masing- masing aspek cukup besar.

2) Berdasarkan data hasil pengamatan diketahui bahwa siswa aktif selama proses belajar berlangsung.

3) Kekurangan pada siklus-siklus sebelumnya sudah mengalami perbaikan dan peningkatan sehingga menjadi lebih baik.

4) Kemampuan berbicara siswa pada siklus III mencapai ketuntasan.

\section{Revisi Pelaksanaan}

Pada siklus III guru telah menerapkan pembelajaran dengan Guide Teaching dengan baik dan dilihat dari aktivitas siswa serta kemampuan berbicara siswa pelaksanaan proses belajar mengajar sudah berjalan dengan baik. Maka tidak diperlukan revisi terlalu banyak, tetapi yang perlu diperhatikan untuk tindakan selanjutnya adalah memaksimalkan dan mempertahankan apa yang telah ada dengan tujuan agar pada pelaksanaan proses belajar mengajar selanjutnya penerapan model pengajaran Guide Teaching dapat meningkatkan proses belajar mengajar sehingga tujuan pembelajaran dapat tercapai. Dari beberapa hasil siklus dapat dilihat sebagai grafik dibawah ini

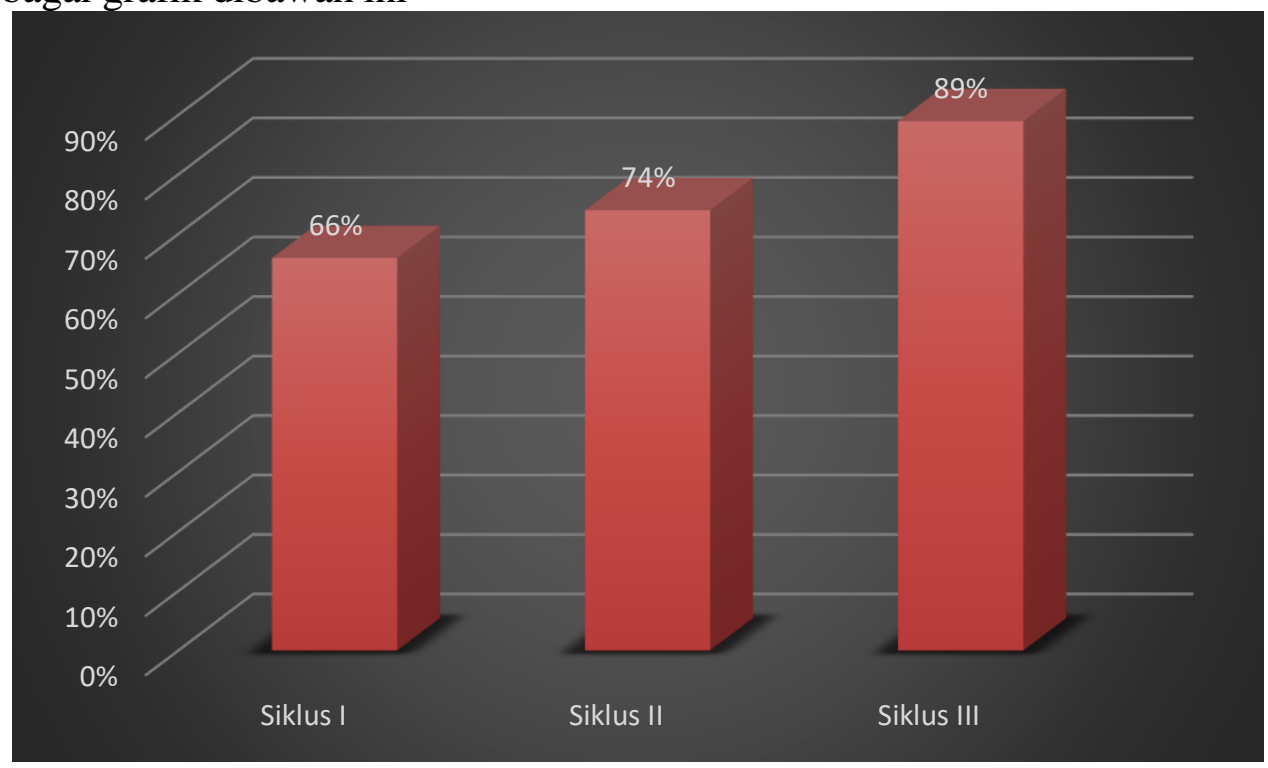

Gambar 2. Grafik Perbadingan Siklus I, Siklus II, dan Siklus III

\section{Pembahasan}

\section{Ketuntasan Kemampuan berbicara Siswa}

Melalui hasil penelitian ini menunjukkan bahwa pembelajaran dengan Guide Teaching memiliki dampak positif dalam meningkatkan prestasi belajar siswa. Hal ini dapat dilihat dari 
semakin mantapnya pemahaman siswa terhadap materi yang disampaikan guru (ketuntasan belajar meningkat dari siklus I, II, dan III) yaitu masing-masing 66\%, 74\%, dan $89 \%$. Pada siklus III ketuntasan belajar siswa secara klasikal telah tercapai.

\section{Kemampuan Guru dalam Mengelola Pembelajaran}

Berdasarkan analisis data, diperoleh aktivitas siswa dalam proses belajar mengajar dengan menerapkan model pengajaran Guide Teaching dalam setiap siklus mengalami peningkatan. Hal ini berdampak positif terhadap prestasi belajar siswa yaitu dapat ditunjukkan dengan meningkatnya nilai rata-rata siswa pad setiap siklus yang terus mengalami peningkatan.

\section{Aktivitas Siswa Dalam Pembelajaran}

Berdasarkan analisis data, diperoleh aktivitas siswa dalam proses pembelajaran Bahasa Inggris dengan model pengajaran Guide Teaching yang paling dominan adalah, mendengarkan/memperhatikan penjelasan guru, dan diskusi antar siswa/antara siswa dengan guru. Jadi dapat dikatakan bahwa aktivitas siswa dapat dikategorikan aktif.

Sedangkan untuk aktivitas guru selama pembelajaran telah melaksanakan langkahlangkah kegiatan belajar mengajar dengan menerapkan pengajaran konstekstual model pengajaran berbasis masalah dengan baik. Hal ini terlihat dari aktivitas guru yang muncul di antaranya aktivitas membimbing dan mengamati siswa dalam menemukan konsep, menjelaskan materi yang sulit, memberi umpan balik/evaluasi/tanya jawab dimana prosentase untuk aktivitas di atas cukup besar.

\section{KESIMPULAN}

Berdasarkan hasil penelitian yang telah d Bahasa Inggris parkan selama tiga siklus, hasil seluruh pembahasan serta analisis yang telah dilakukan dapat disimpulkan sebagai berikut:

1. Model pengajaran Guide Teaching dapat meningkatkan kualitas pembelajaran Bahasa Inggris materi Talking about Self .

2. Pembelajaran dengan Guide Teaching memiliki dampak positif dalam meningkatkan prestasi belajar siswa yang ditandai dengan peningkatan ketuntasan belajar siswa dalam setiap siklus, yaitu siklus I (66\%,), siklus II (74\%), siklus III (89\%).

3. Model pengajaran Guide Teaching dapat menjadikan siswa merasa dirinya mendapat perhatian dan kesempatan untuk menyampaikan pendapat, gagasan, ide dan pertanyaan.

4. Siswa dapat bekerja secara mandiri maupun kelompok, serta mampu mempertanggungjawabkan segala tugas individu maupun kelompok.

5. Penerapan pembelajaran dengan Guide Teaching mempunyai pengaruh positif, yaitu dapat meningkatkan kreatifitas belajar siswa.

\section{DAFTAR PUSTAKA}

Agus Suprijono. (2009). Cooperatif Learning. Yongyakarta: Pustaka Pelajar.

Ahmadi, Abu dan Widodo Supriyono. (2003). Psikologi Belajar, Jakarta; PT. Rineka Cipta

Arifin, M. (1997). Filasafat Pendidikan Islam. Jakarta Bumi Aksara,

Arikunto, Suharsimi. (1998). Prosedur Penelitian Suatu Pendekatan praktek. Jakarta: Rineka Cipta

Azhar, Mohammad. (1996). Fiqih Kontemporer dalam Pandangan Neomodernisme Islam. Yogyakarta: Lesiska

Departemen Pendidikan Nasional. (2007). Kamus Besar Bahasa Indonesia. Jakarta: Balai Pustaka

Dimyati dan Mudjiono. (1999). Belajar dan Pembelajaran. Jarkarta; PT. Rineka Cipta,

Djamarah, Bahri Syaiful dan Zain, Aswan. (1997). Strategi Belajar Mengajar. Jakarta; PT. Rineka Cipta

Sudjana, Nana. (1998). Dasar-Dasar Proses Belajar Mengajar. Bandung : Sinar Baru Algensindo 